\title{
Study on health hazards through medicines purchased on the Internet: a cross-sectional investigation of the quality of anti-obesity medicines containing crude drugs as active ingredients
}

Naoko Yoshida ${ }^{1 *}$, Midori Numano², Yoko Nagasaka², Kaori Ueda' , Hirohito Tsuboi ${ }^{1}$, Tsuyoshi Tanimoto² and Kazuko Kimura ${ }^{1}$

\begin{abstract}
Background: Weight-loss medicines, including crude drugs and herbal supplements disguised as diet-aid products, are readily obtainable and distributed widely, especially in Southeast Asia. Even if such products are unapproved or prescription-only medicines, consumers can purchase them through an agency or directly on the Internet. We evaluated the quality and safety of herbal products purchased on the Internet to reveal their influence on public health.

Methods: Diet-aid products containing Bukuryo (Poria sclerotium), Bakumondo (Ophiopogonis tuber), or Daio (rhubarb rhizome) were purchased through websites that did not provide physical addresses or which advertised misleading medicines (e.g., unapproved Cialis $100 \mathrm{mg}$ tablets, Viagra $100 \mathrm{mg}$ tablets) on websites. We carefully noted details in the descriptions on package inserts or accompanying product characteristics and analyzed the ingredients using qualitative and quantitative methods, namely high-performance liquid chromatography equipped with a photodiode array detector. We requested the respective manufacturers to authenticate their products through a structured questionnaire.

Results: We purchased 15 items from 15 Internet sites and imported all 15 items to Japan. One item stated to contain rhubarb rhizome was identified as a prescription medicine; the others were dietary supplements and not medicines. Even though we did not analyze the constituents of all crude drugs, we found some active ingredients in the items. Sibutramine was detected in items confirmed to be supplements, including those containing Poria sclerotium and Ophiopogonis tuber. Each capsule contained $\approx 12 \mathrm{mg}$ of sibutramine, which is the daily dose for anti-obesity medicines. Sibutramine is not approved for use in Japan and its sale has been suspended in Europe and the USA owing to serious adverse effects on the circulatory system.

Conclusions: Our findings indicate that dietary supplements containing injurious ingredients are distributed to Japanese consumers and potentially to a broader international audience, and that purchasing them through unreliable websites bears potential health risks. To avoid potential adverse events, there should be adequate alerts about the risks of taking products without appropriate indications.
\end{abstract}

Keywords: Suspended medicines, Diet aid products, Anti-obesity medicines, Sibutramine, Personal import, Internet

\footnotetext{
* Correspondence: naoko@p.kanazawa-u.ac.jp

'Drug Management and Policy, Faculty of Pharmacy, Institute of Medical, Pharmaceutical and Health Sciences, Kanazawa University, Kakuma-machi, Kanazawa, Ishikawa 920-1192, Japan

Full list of author information is available at the end of the article
}

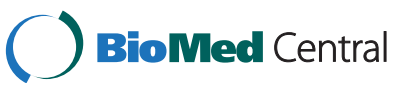

(c) 2015 Yoshida et al. Open Access This article is distributed under the terms of the Creative Commons Attribution 4.0 International License (http://creativecommons.org/licenses/by/4.0/), which permits unrestricted use, distribution, and reproduction in any medium, provided you give appropriate credit to the original author(s) and the source, provide a link to the Creative Commons license, and indicate if changes were made. The Creative Commons Public Domain Dedication waiver (http://creativecommons.org/publicdomain/zero/1.0/) applies to the data made available in this article, unless otherwise stated. 


\section{Background}

The increasing international trade in pharmaceuticals via sales on the Internet has facilitated the entry of counterfeit products into the supply chain. Counterfeit products include products with ingredients different from those labeled or advertised, without active ingredients, with insufficient or excessive active ingredients, and with misleading packaging [1]. Since 2011, the World Health Organization (WHO) has suggested that counterfeit medicines be termed "spurious/falsely labelled/falsified/counterfeit" (SFFC) medicines [2]. In parallel, Attran and colleagues recommended reserving the term "falsified" for crimes against public health [3]. They defined "falsified medicines" as medicines that violate the quality specifications of the regulator-but what truly defines and distinguishes them is criminal intent [3]. Use of such medicines can result in treatment failure or even death. The WHO has warned that medicines purchased over the Internet from sites that conceal their physical addresses are falsified in $>50 \%$ of cases [1]. An individual can import restricted quantities of medication for personal use without undergoing special procedures in Japan [4]. Accordingly, pharmaceutical regulatory authorities in many countries and regions such as the Ministry of Health, Labour and Welfare in Japan [5], the US Food and Drug Administration [6,7], European Medicines Agency [8], Medicines and Healthcare Products Regulatory Agency in the United Kingdom [9, 10], Health Canada [11], and the Therapeutic Goods Administration in Australia [12], promote awareness regarding medicines that should be avoided and not purchased over the Internet.

Obtaining accurate information on the extent of falsified medicines is difficult because the falsified medicines detected are a small proportion of the total number of falsified medicines that are available. Because of this situation, sharing information and promoting awareness in regard to falsified medicines may help to combat the health hazards associated with the use of falsified medicines. Preventing health hazards is a societal requirement. It is necessary to avert the serious adverse effects of imported medicines by undertaking countermeasures supported by field-based and scientific evidence. Our research team has highlighted the public-health implications of privately importing medicines such as levonorgestrel and piracetam (which are prescription medicines in Japan) [13, 14].

Among privately imported medicines in Japan, antiobesity medicines are the most popular, followed by medicines for erectile dysfunction and hair growth [15]. Reductil $^{\circ}$ contains sibutramine, and is one of the most popular anti-obesity agents found on websites, but it is not approved in Japan. In one Reductil-containing product imported via the Internet, the maximum dose of sibutramine described in the explanatory note in Japanese was nearly three-times the dose described in the true package insert, but this item was confirmed as "authentic" by the manufacturer [14]. In 2012, it was reported that a product labeled Xenical ${ }^{\circ}$ (120 mg orlistat), a synthetic anti-obesity medicine imported via the Internet, had no active ingredient except starch. Furthermore, it was a falsified medicine according to the response from the manufacturer to our requests for authentication [16].

In the present study, we investigated the quality of samples of diet-aid products and weight-loss medicines purchased on the Internet using chemical analyses.

\section{Methods}

\section{Sample collection}

Using Japanese keywords for "personal import agent", "slimming" and "obesity" (terms used in a list of "plantorigin materials used mainly as pharmaceutical medicine" created by the Ministry of Health, Labour and Welfare in Japan [17]), we searched for diet-aid products that were described on Internet sites as containing Bukuryo (Poria, Poria sclerotium), Bakumondo (Ophiopogonis tuber), or Daio (rhubarb rhizome) on the Japanese Google search engine (www.google.co.jp). Among the websites advertising such products, we selected those sellers that did not disclose their physical addresses and those that advertised the sale of falsified medicines (e.g., with unapproved dosages) in August 2009 to purchase the items mentioned above [16]. Poria, Ophiopogonis tuber and rhubarb have been approved for reimbursement under Japanese national health insurance as prescription and over-the-counter medicines. These crude drugs are used widely as diuretics or purging agents in Japan.

\section{Observation}

We carefully noted the descriptions (ingredients, quantity, dosage form, package presentation, usage instructions, safety information, manufacture date, expiration date, batch number, name and address of the manufacturer) on the website and package insert or the summary of product characteristics of the items purchased.

\section{Authenticity investigation}

The methodology of the authenticity investigation and registration verification was adopted from that provided by the WHO $[16,18]$. We requested the respective manufacturers to authenticate their products through a structured questionnaire (including verification of the descriptions on the package, equivalence in appearance, and licensed status for manufacturing and marketing) sent by post together with a part or photograph of the items. 


\section{Materials}

We purchased benfluorex, orlistat, and aristolochic acid (mixture of I and II) from Sigma-Aldrich Co. LLC (Saint Louis, MO, USA). Lovastatin was purchased from Toronto Research Chemicals (Toronto, ON, Canada). We bought rimonabant from Cayman Chemical Company (Ann Arbor, MI, USA), and sibutramine hydrochloride from Tocris Bioscience (Minneapolis, MN, USA). We purchased fenfluramine and $\mathrm{N}$-nitroso-fenfluramine from Wako Pure Chemical Industries, Ltd. (Osaka, Japan). These compounds were the reference standards of the compounds that were not listed on the package or insert. To verify that rhubarb rhizome was present, sennoside A (one of the anthraquinone glycosides in rhubarb and a compound used for identification of rhubarb rhizome according to the Japanese Pharmacopoeia 16) and authentic rhubarb rhizome were purchased from Nacalai Tesque, Inc. (Kyoto, Japan) and Tochimoto Tenkaido Co., Ltd. (Osaka, Japan), respectively. The reference standards of the other anthraquinone glycosides, aloe-emodin and emodin were purchased, respectively, from Toronto Research Chemicals and Tokyo Chemical Industry Co., Ltd. (Tokyo, Japan). Rhein and chrysophanol were bought from Extrasynthese S.A. (Genay, France). High-performance liquid chromatography (HPLC)-grade reagents of acetonitrile, 2-propanol, methanol, and trifluoroacetic acid were purchased from Wako Pure Chemical Industries, Ltd. All other chemicals were available commercially and of analytic grade. A membrane filter (Millex ${ }^{\oplus}$-LG; pore size, $0.20 \mu \mathrm{m}$; Merck Millipore, Billerica, MA, USA) was used for filtration treatment for HPLC analyses. Thin-layer chromatography (TLC; silica gel 60 F254; $20 \times 20 \mathrm{~cm}$, Merck, Billerica, MA, USA) was employed for analyses.

\section{Sample preparation}

We categorized purchased materials into three types of dosage form: soft capsules, hard capsules, and sugarcoated tablets. For soft capsule samples, we cut the capsules open, weighed the contents, transferred them to a $100-\mathrm{mL}$ volumetric flask, and added an appropriate quantity of mobile phase. This solution was mixed by shaking for $90 \mathrm{~s}$, passed through a membrane filter and analyzed. For hard capsule samples, we weighed the content in the capsule, which was sonicated with $\approx 80 \mathrm{~mL}$ of methanol for $30 \mathrm{~min}$ and diluted to $100 \mathrm{~mL}$ in a volumetric flask. The diluent was passed through a membrane filter and analyzed. For the sugarcoated tablet sample, we removed the coating with water. Thereafter, the whole of the uncoated tablet was sonicated with $\approx$ $80 \mathrm{~mL}$ of methanol for $30 \mathrm{~min}$ and diluted to $100 \mathrm{~mL}$ in a volumetric flask. The diluent was passed through a membrane filter and analyzed.
We dissolved each of the reference standards of sennoside A, aloe-emodin, chrysophanol, emodin, and rhein (1 mg) in $10 \mathrm{~mL}$ of ethanol. We passed each solution through a membrane filter and analyzed them.

To extract rhubarb rhizome, we pulverized adequate amounts of rhubarb rhizome. To $1 \mathrm{~g}$ of pulverized rhubarb rhizome, we added $10 \mathrm{~mL}$ of ethanol and then sonicated it for $10 \mathrm{~min}$ (2510 J-MF; Branson Ultrasonic Corporation, Danbury, CT, USA), and centrifuged it for $5 \mathrm{~min}(800 \times g)$. The supernatant was passed through a membrane filter and analyzed using TLC.

To $200 \mathrm{mg}$ of pulverized rhubarb rhizome, we added $4 \mathrm{~mL}$ of ethanol, sonicated it for $10 \mathrm{~min}$, and centrifuged it for $5 \mathrm{~min}(800 \times \mathrm{g})$. A diluent of $1 \mathrm{~mL}$ of supernatant with $3 \mathrm{~mL}$ of ethanol was filtered and injected into the HPLC system.

\section{HPLC analyses}

The three HPLC methods described below were employed to detected benfluorex, lovastatin, rimonabant, sibutramine hydrochloride, orlistat, aloe-emodin, chrysophanol, emodin, rhein, aristolochic acid, fenfluramine, and $\mathrm{N}$ nitroso-fenfluramine. To identify the compounds contained in purchased items, we confirmed that a single peak appeared upon simultaneous injection with the reference standard of the substance.

\section{System suitability}

HPLC was undertaken according to the method described in the Japanese Pharmacopoeia 16 [19]. Each product was analyzed before the expiry date detailed on the label.

\section{Method 1}

Benfluorex, rimonabant, sibutramine hydrochloride and orlistat are well known synthetic anti-obesity compounds. Lovastatin is a cholesterol-lowering statin and has often been mistaken for having anti-obesity effects. We carried out quantitative determination of benfluorex, lovastatin, rimonabant, sibutramine hydrochloride, and orlistat with the calibration curves constructed for a HPLC system equipped with a photodiode array (PDA) detector (LC-20 AD; Shimadzu, Kyoto, Japan) according to the method for chemical analyses described in our previous study [16]. The analytical column was a Mightysil RP-18GP $(4.6 \times 150$ mm, $5 \mu \mathrm{m}$; Kanto Chemical Co., Inc., Tokyo, Japan). The column temperature was maintained at $45{ }^{\circ} \mathrm{C}$ using a column oven (CTO-20A; Shimadzu). The mobile phase was a mixture of methanol and $0.02 \mathrm{~mol} / \mathrm{L}$ phosphate buffer, $\mathrm{pH} 7.0,(17: 3, v / v)$. The flow rate was $1.2 \mathrm{~mL} / \mathrm{min}$. The detection wavelength was $225 \mathrm{~nm}$ and we recorded ultraviolet (UV) spectra at 200-400 nm (SPD-M20A; Shimadzu). The injection volume was $20 \mu \mathrm{L}$. Under these conditions, benfluorex, 
Table 1 Item information

\begin{tabular}{|c|c|c|c|c|c|c|c|c|}
\hline \multirow[t]{2}{*}{$\begin{array}{l}\text { Item } \\
\text { number }\end{array}$} & \multirow[t]{2}{*}{$\begin{array}{l}\text { Product } \\
\text { code }\end{array}$} & \multirow[t]{2}{*}{$\begin{array}{l}\text { Product name displayed } \\
\text { on package }\end{array}$} & \multirow[t]{2}{*}{$\begin{array}{l}\text { Name of holder of marketing } \\
\text { authorization }\end{array}$} & \multirow{2}{*}{$\begin{array}{l}\text { Country of holder } \\
\text { of marketing } \\
\text { authorization }\end{array}$} & \multirow{2}{*}{ Approval status } & \multirow[t]{2}{*}{$\begin{array}{l}\text { Ingredients displayed on package (scientific } \\
\text { or common name) }\end{array}$} & \multicolumn{2}{|c|}{$\begin{array}{l}\text { Description of sibutramine } \\
\text { containing }\end{array}$} \\
\hline & & & & & & & $\begin{array}{l}\text { Package or } \\
\text { insert }\end{array}$ & Website \\
\hline 1 & $A$ & 韓国瘦身1号(美体型) & 西安華威保健有限公司 & China & Supplement & $\begin{array}{l}\text { 山楂 (Crataegi fructus), 获苓 (Poria sclerotium), } \\
\text { 菜菔子 (Raphani semen) }\end{array}$ & No & No \\
\hline 2 & B & 終極瘦身 & 西安華威保健有限公司 & China & Supplement & $\begin{array}{l}\text { 蘭姬花, 櫻花素, 錦带花, 珍珠粉 (pearl powder), } \\
\text { 蒕薯 (aloe), 核桃油 (walnut oil) }\end{array}$ & No & No \\
\hline 3 & C & 韓国瘦身1号(美腿型) & 西安華威保健有限公司 & China & Supplement & $\begin{array}{l}\text { 获苓 (Poria sclerotium), 菜菔子 (Raphani semen), } \\
\text { 苦宁素 }\end{array}$ & No & No \\
\hline 4 & D & 韓国瘦身1号(収腹提慰型) & 西安華威保健有限公司 & China & Supplement & $\begin{array}{l}\text { 山楂 (Crataegi fructus Fructus), 香茶素, 决明子 } \\
\text { (Cassiae semen), 荷叶素 }\end{array}$ & No & No \\
\hline 5 & B & 終極瘦身 & 西安華威保健有限公司 & China & Supplement & $\begin{array}{l}\text { 蘭姫花, 櫻花素, 錦帯花, 珍珠粉 (pearl powder), } \\
\text { 䓝曾 (aloe), 核桃油 (walnut oil) }\end{array}$ & No & No \\
\hline 6 & E & $\begin{array}{l}\text { 韓国瘦身1号(新1代)(美体 } \\
\text { 型) }\end{array}$ & 西安華威保健有限公司 & China & Supplement & $\begin{array}{l}\text { 山楂 (Crataegi fructus Fructus), 获苓 (Poria } \\
\text { Sclerotium), 菜菔子 (Raphani semen) }\end{array}$ & No & No \\
\hline 7 & $\mathrm{~F}$ & $\begin{array}{l}\text { 韓国瘦身1号(新1代)(収腹 } \\
\text { 提整) }\end{array}$ & 西安華威保健有限公司 & China & Supplement & $\begin{array}{l}\text { 山楂 (Crataegi fructus Fructus), 香茶素, 决明子 } \\
\text { (Cassiae semen), 荷叶素 }\end{array}$ & No & No \\
\hline 8 & G & RELACORE & $\begin{array}{l}\text { America Leptin Phrmaceuticals } \\
\text { Limited }\end{array}$ & USA & Supplement & Not listed & No & No \\
\hline 9 & $\mathrm{H}$ & 代代花胶囊 & $\begin{array}{l}\text { Kuming Dali Industry \& Trade } \\
\text { Co., Ltd. }\end{array}$ & China & Supplement & 代代花 (Citrus aurantii flos) & No & Yes \\
\hline 10 & । & 妙姿 & 百年医药集団有限公司 & China & Supplement & $\begin{array}{l}\text { 山楂 (Crataegi fructus Fructus), 蘆蕒 (Aloe), 枳実 } \\
\text { (Aurantii Fructus immaturus), 桃仁 (Persicae semen) }\end{array}$ & No & No \\
\hline 11 & J & 韓国緑素抗脂胶囊 & $\begin{array}{l}\text { 珠海尚高乐实业发展有限公 } \\
\text { 司 }\end{array}$ & China & Supplement & $\begin{array}{l}\text { 奇昇果, 茶叶, 决明子 (Cassiae semen), 荷叶素, } \\
\text { 山楂 (Crataegi fructus Fructus), 麦冬(Ophiopogonis } \\
\text { tuber), 檳榔 (Areca semen), 青皮 (Citrus unshiu } \\
\text { pericarpium immaturus) }\end{array}$ & No & No \\
\hline 12 & J & 韓国緑素抗脂胶囊 & $\begin{array}{l}\text { 珠海尚高乐实业发展有限公 } \\
\text { 司 }\end{array}$ & China & Supplement & $\begin{array}{l}\text { 奇昇果, 茶叶, 决明子 (Cassiae semen), 荷叶素, } \\
\text { 山楂 (Crataegi Fructus Fructus), 麦冬(Ophiopogonis } \\
\text { tuber), 檳榔 (Arecae semen), 青皮 (Citrus unshiu } \\
\text { pericarpium immaturus) }\end{array}$ & No & No \\
\hline 13 & J & 韓国緑素抗脂胶囊 & $\begin{array}{l}\text { 珠海尚高乐实业发展有限公 } \\
\text { 司 }\end{array}$ & China & Supplement & $\begin{array}{l}\text { 奇昇果, 茶叶, 决明子 (Cassiae Cassiae semen), } \\
\text { 荷叶素, 山楂 (Crataegi Fructus), 麦冬(Ophiopogonis } \\
\text { tuber), 檳榔 (Arecae semen), 青皮 (Citrus unshiu } \\
\text { pericarpium immaturus) }\end{array}$ & No & No \\
\hline 14 & K & 軽身減肥片 & 陕西君寿堂制药有限公司 & China & $\begin{array}{l}\text { Prescription } \\
\text { medicine }\end{array}$ & $\begin{array}{l}\text { 大黄 (rhubarb rhizome), 防已 (Sinomeni caulis } \\
\text { et rhizoma), 丹参 (Salviae Miltiorrhizae radix), 茵陝 } \\
\text { (Artemisiae Capillaris herba), 沢江 (Alismatis rhizoma), } \\
\text { 山楂 (Crataegi fructus Fructus), 水牛角, 淫羊蕉 } \\
\text { (Epimedii herba), 黄芪 (Astragali radix), 白术 } \\
\text { (Atractylodis rhizoma), 川芦 (Cnidii rhizoma) }\end{array}$ & No & No \\
\hline 15 & C & 韓国瘦身1号(美腿型) & 西安華威保健有限公司 & China & Supplement & $\begin{array}{l}\text { 获苓 (Poria sclerotium), 菜菔子 (Raphani semen), } \\
\text { 苦宁素 }\end{array}$ & No & No \\
\hline
\end{tabular}


lovastatin, rimonabant, sibutramine hydrochloride, and orlistat were eluted in that order and separated completely in the chromatogram (data not shown). The standard ingredient was identified by its retention time and absorption spectrum. To prepare solutions of standards, we dissolved benfluorex, lovastatin, rimonabant, sibutramine hydrochloride, or orlistat with methanol and diluted them stepwise to the appropriate concentration.

\section{Method 2}

We detected aloe-emodin, chrysophanol, emodin, and rhein (the active ingredients of rhubarb rhizome) using the HPLC-PDA system. The analytical column was as described for Method 1. We maintained the column temperature at $45{ }^{\circ} \mathrm{C}$ using a column oven (CTO-10Avp; Shimadzu). For the mobile phase, we prepared a mixture of methanol, acetonitrile, and $0.1 \%$ formic acid (8:1:1, $v /$ $v / v)$. The flow rate was $1.0 \mathrm{~mL} / \mathrm{min}$. We set the detection wavelength at $254 \mathrm{~nm}$ and recorded UV spectra at 200-400 nm (SPD-M10Avp; Shimadzu). The injection volume was $10 \mu \mathrm{L}$.

\section{Method 3}

Aristolochic acid is a harmful compound found in Chinese herbal supplements that promote anti-obesity and which are imported via the Internet [20, 21]. Fenfluramine and $\mathrm{N}$-nitroso-fenfluramine are also harmful compounds which have anti-obesity effects similar to those of sibutramine [22]. Chromatograms were recorded for the standard compounds of aristolochic acid, fenfluramine, and $\mathrm{N}$-nitroso-fenfluramine using the HPLC-PDA system according to methods described in the Japanese Pharmacopoeia 16 [19]. The analytical column was a Cosmosil C18-AR-II $(4.6 \times 150 \mathrm{~mm}, 5 \mu \mathrm{m}$; Nacalai Tesque, Inc.). We maintained the column temperature at $40{ }^{\circ} \mathrm{C}$ using a column oven (CTO-20 AC; Shimadzu). The flow rate was $1.0 \mathrm{~mL} / \mathrm{min}$. We recorded UV spectra at 200-400 nm (SPD-M10Avp; Shimadzu). The injection volume was $10 \mu \mathrm{L}$.

To detect aristolochic acid, a mobile phase (methanol and $0.02 \mathrm{M}$ phosphate buffer at $\mathrm{pH} 7.0(1: 1, v / v))$ was prepared. We set the detection wavelength at $310 \mathrm{~nm}$. To detect fenfluramine and N-nitroso-fenfluramine, we prepared a mobile phase (methanol and water $(4: 6, v / v)$ ) to which we added, respectively, $1 \mathrm{~mL}$ of trifluoroacetic acid and a mixture of methanol and $0.2 \%$ trifluoroacetic acid solution $(3: 2, v / v)$. We set the detection wavelength at $210 \mathrm{~nm}$.

\section{TLC analyses}

We detected the ingredients in the sugarcoated tablet supposedly containing rhubarb rhizome and the extract of authentic rhubarb rhizome with reference to the monograph on rhubarb rhizome in the Japanese Pharmacopoeia
16 [19] and compared them. We developed a plate with a mixture of 1-propanol, ethyl acetate, water, and acetic acid $(40: 40: 30: 1, v / v / v / v)$ to $\approx 40 \mathrm{~mm}$. We observed spots under UV light at 254 nm (SLUV-6; 254/365 nm; As One, Osaka, Japan).

\section{Results}

We purchased 15 items 11 products from six manufacturers sold on 15 Internet sites. Among the 15 websites, five lacked a description of their physical addresses, and four, one, and five sites advertised falsified Cialis, Levitra, and Viagra, respectively. These falsified products had unapproved content or dosage forms.

Of the 15 items, 11 items from eight products contained Poria, three items from one product contained Ophiopogonis tuber, and one item contained rhubarb rhizome. One item containing rhubarb rhizome was confirmed to be authentic and was a prescription medicine according to the reply from the manufacturer; the others were dietary supplements and not medicines. We noted the crude-drug components of each item listed in the descriptions on the outer packaging or package inserts (Table 1). For one item, no information about such components was provided.

Items purchased from the 15 websites were sent by nine dispatchers, including one whose shipping label was indecipherable. All dispatchers were located in China. Of the six manufacturers, one was located in the USA, and the others were in China.

In the authenticity investigation, only one of the six manufacturers replied: the item containing rhubarb rhizome manufactured by the respondent was confirmed to be a genuine product according to the manufacturer's reply. With three manufacturers, the questionnaires were returned because the address was incomplete, or the website provided on the outer packaging could not be accessed. Two e-mail addresses of these three manufacturers were not deliverable.

We categorized the 15 items into three types of dosage form: there were eight soft-capsule samples, six hardcapsule samples, and one sugarcoated-tablet sample.

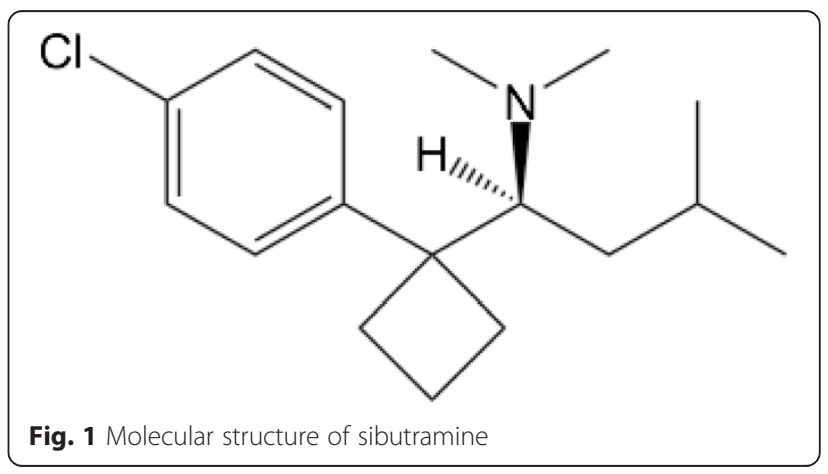




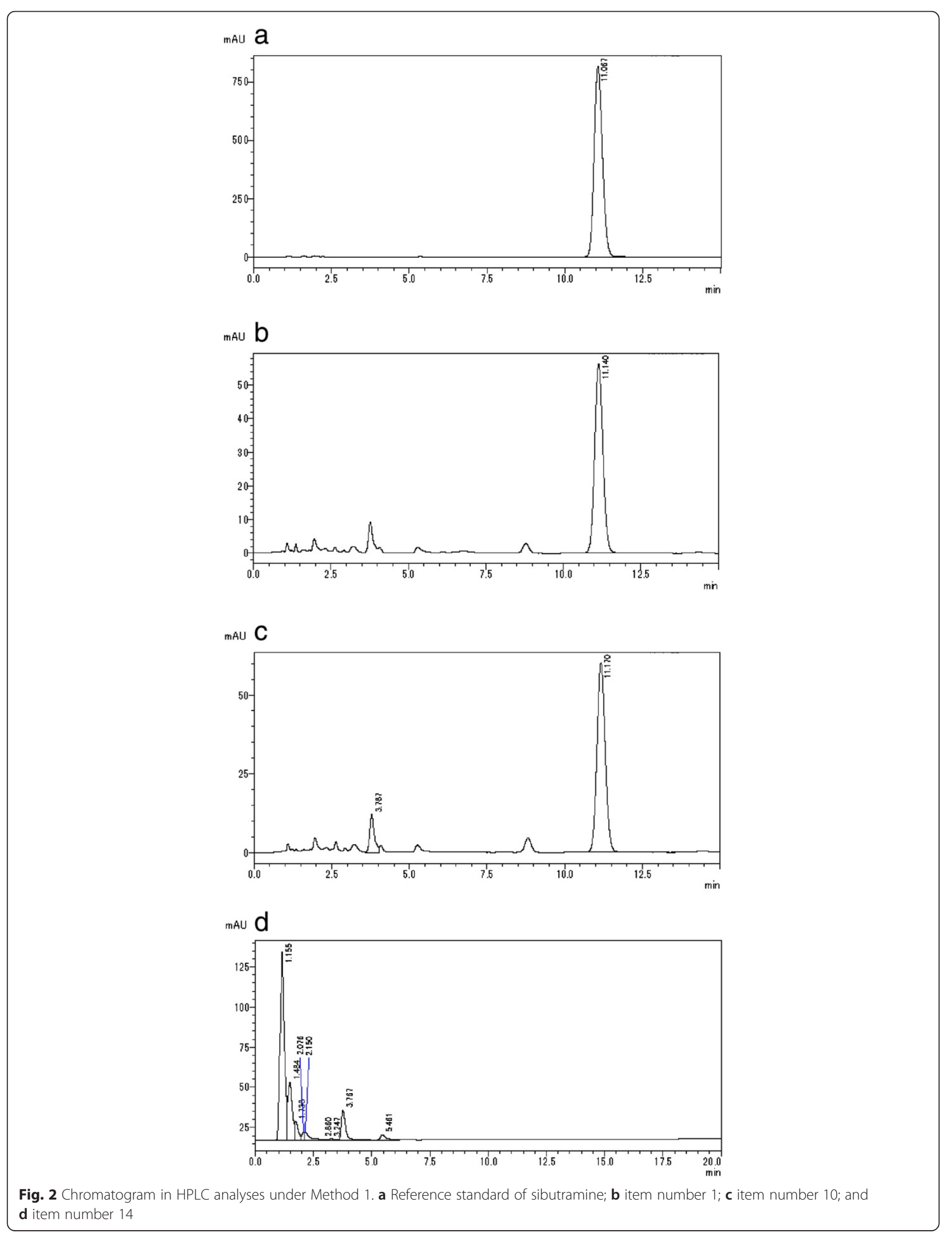




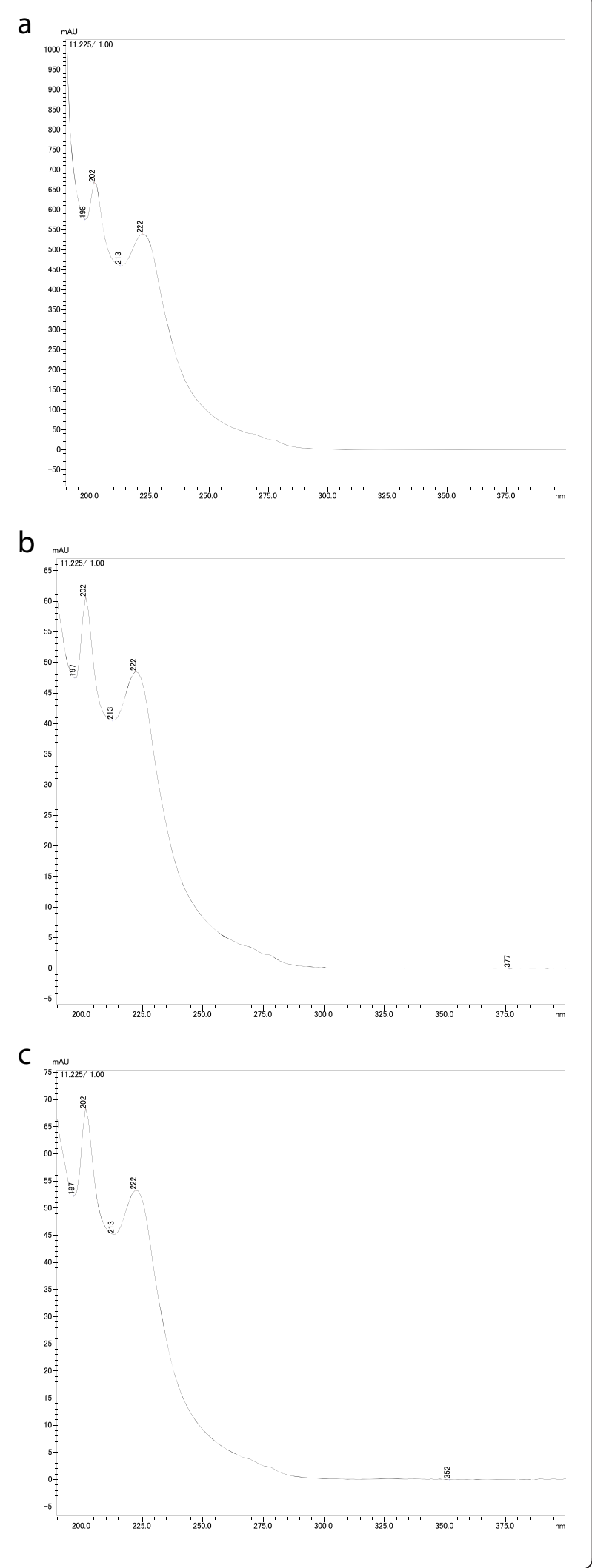

Fig. 3 Absorbance spectrum of the peaks that appeared in HPLC analyses under Method 1. a Reference standard of sibutramine; b the peak that appeared in HPLC analyses of item number 1; and $\mathbf{c}$ the peak that appeared in HPLC analyses of item number 10

One soft-capsule sample could not be analyzed because of an insufficient number of capsules. All soft-capsule samples were filled with a clear, oily liquid. In the chromatogram of this fluid dissolved in the mobile phase for HPLC analyses, we found that the analytic procedure (Method 1) revealed a peak. The retention time of this peak was $\approx 11 \mathrm{~min}$, which is consistent with sibutramine hydrochloride (Figs. 1, 2a, b). In addition to the retention time, the absorbance spectrum of this peak showed close similarity to that of the reference standard of sibutramine hydrochloride (Fig. 3a, b). No other isolated peak was detected. All seven soft-capsule samples, which were not described as containing sibutramine, showed this characteristic chromatogram.

All hard-capsule samples had fawn- or tan-colored granular contents, which contained plant fragments as according to microscopic examination. After dissolving these contents in methanol, HPLC Method 1 revealed a peak at $\approx 11 \mathrm{~min}$ (Fig. 2c). The retention time and absorbance spectrum of this peak showed a close similarity to that of the reference standard sibutramine hydrochloride (Figs. 2a, c, 3a, c). All six hard-capsule samples showed this characteristic chromatogram. Other distinct peaks of the crude drug components appeared over 12.5 min.

After removing its coating, the one sugarcoated tablet preparation (number 14) was found to have brown contents. In the TLC analyses, sennoside A (the subject of identification of rhubarb rhizome in the Japanese Pharmacopoeia 16) was not detected in the extract of this item, whereas the spot derived from sennoside A appeared in the extract of rhubarb rhizome (data not shown). In HPLC analyses under Method 1, some peaks appeared at 1-5 min; no peak was detected at $\approx 11 \mathrm{~min}$ in the chromatogram of this extract with methanol (Fig. 2d); no peaks appeared after 5 min when analyses were undertaken with the coating agents removed. The diluent with methanol showed some peaks in the chromatogram under Method 2, and these peaks were consistent with the pattern of extract of rhubarb rhizome (Fig. 4a, b). The retention time and absorbance spectrum of four of the five types of peaks (Fig. 5-1, 5-2, 5-3, 5-4, $5-5,5 \mathrm{a}, \mathrm{b}, \mathrm{c}, \mathrm{d}, \mathrm{e})$ showed a close similarity to those of the reference standards of aloe-emodin (Figs. 4c, 5i), rhein (Figs. 4d, 5-ii), emodin (Figs. 4e, 5-iii), and chrysophanol (Figs. 4f, 5-iv), but one of them was not known (Figs. 4a, b, 5-5, 5e). The constituent of another peak could not be identified. 

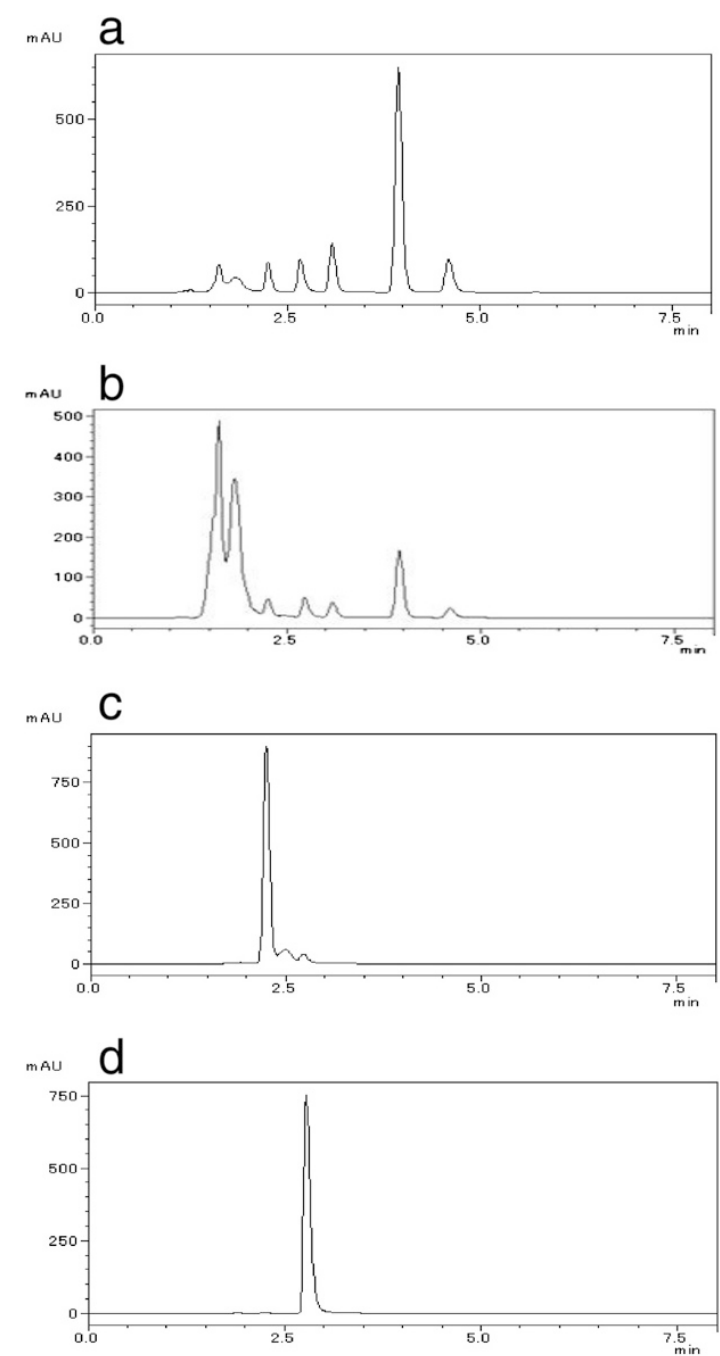

maU $e$

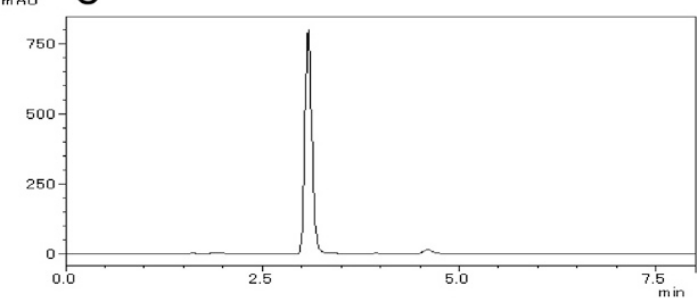

mau $f$

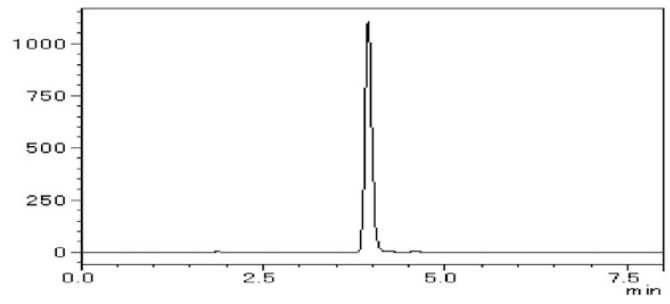

Fig. 4 Chromatogram in HPLC analyses under Method 2. Item number 14: an extract of rhubarb rhizome and reference standards of anthraquinones in rhubarb rhizome were analyzed by HPLC under Method 2. a, b, c, d, e, and $\mathbf{f}$ show, respectively, the chromatogram of item number 14, and the extracts of rhubarb rhizome, aloeemodin, rhein, emodin, and chrysophanol

In HPLC analyses under Method 3, aristolochic acid, fenfluramine, and $\mathrm{N}$-nitroso-fenfluramine were not detected in any item.

For items containing sibutramine, quantitative analyses were carried out using the HPLC-UV method. The mean quantity of sibutramine in each item was $12.37 \pm 4.63 \mathrm{mg}$; the minimum and maximum were $\approx 6$ and $\approx 25 \mathrm{mg} / \mathrm{cap}-$ sule, respectively (Table 2 ). In one item (number 8 ), the quantity of sibutramine varied among capsules.

\section{Discussion}

We evaluated the quality of imported anti-obesity medicines comprising crude drugs purchased via the Internet. Anti-obesity medicines sold on the Internet include synthetic medicines (e.g., sibutramine hydrochloride, orlistat) as well as crude-drug products and supplements, which are advertised as promoting weight loss. One purchased item containing rhubarb rhizome was identified as a prescription medicine in our authenticity investigation and the others were advertised as dietary supplements that were matched with package information. After HPLC analyses, we determined that the main ingredient of all soft- and hard-capsule samples was the synthetic anti-obesity agent sibutramine (Figs. 2a, b, c, 3 ), but this information was not described on the package, package insert and/or the website except for one item “代代花胶囊 (item number 9)”. On the website advertising 代代花胶囊, we found a description stating that a weight-loss effect owing to sibutramine could be expected (Table 1). Hence, the items confirmed to contain sibutramine could be classified as "falsified products" according to the definition of Attran and colleagues [3]. For the soft-capsule samples, only sibutramine was detected and no crude drugs were found. Among those 13 items, each capsule contained $\approx 12 \mathrm{mg}$ of sibutramine, which was equivalent to or exceeded the recommended daily dose $(10 \mathrm{mg})$ for an anti-obesity medicine. One capsule contained $25 \mathrm{mg}$ of sibutramine.

By contrast, the one sugarcoated tablet preparation did not contain sibutramine hydrochloride, benfluorex, lovastatin, rimonabant, or orlistat (Fig. 2d). The assayed sample of the sugarcoated tablet was found to contain quantities of the major constituents of indicated crude drugs such as the anthraquinones (except for sennoside A) in rhubarb rhizome; the plant fragments in the sample could not be identified (Figs. 4, 5). 

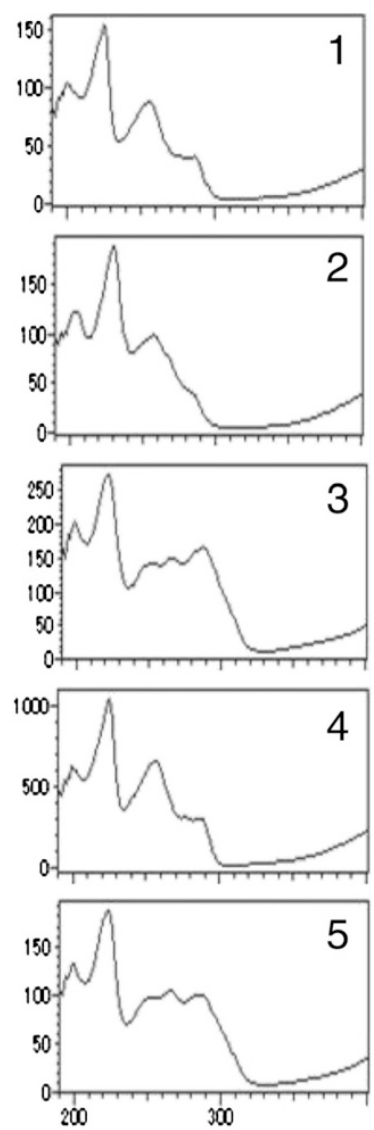
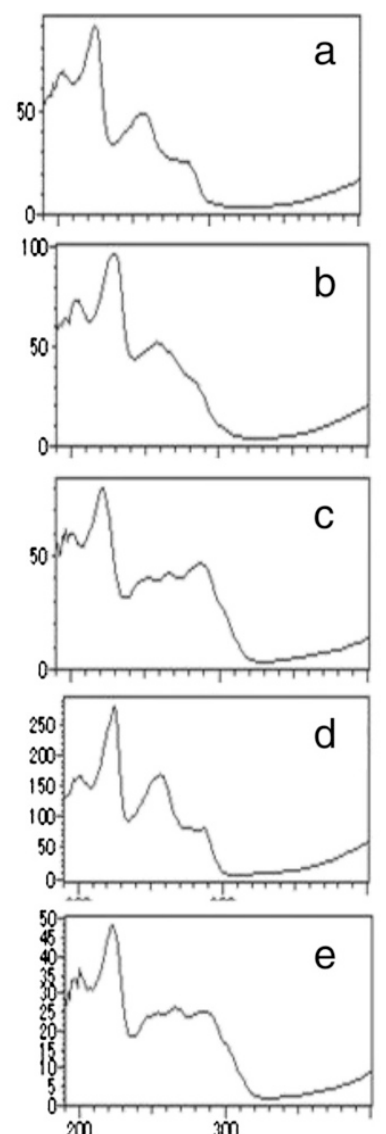
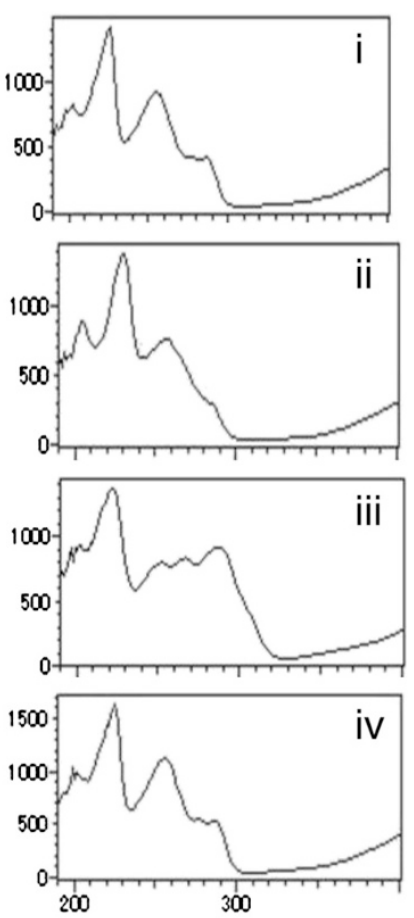

Fig. 5 Absorbance spectrum of the peaks that appeared in HPLC analyses under Method 2. The absorbance spectrum of five types of peaks appeared in the chromatogram of item number $14(1-5)$ and the extract of rhubarb rhizome (a-e); reference standards of aloe-emodin (i), rhein (ii), emodin (iii), and chrysophanol (iv) are shown

These findings indicate that sibutramine was present in most of the herbal supplements that we purchased online and which we assayed. Even supplements that are described as containing only crude drugs should be used carefully because they might contain synthetic adulterants. This is especially true for products purchased from the Internet, for which there is often a lack of compliance to national regulatory standards. Our results indicate that the diet-aid products that we examined may exert an antiobesity effect as a result of the sibutramine, they contained and not through the crude drugs themselves.

With regard to item number 15 (which could not be evaluated because of an insufficient number of capsules), we detected sibutramine in another item (number 3) that had the same product name, lot number, date of manufacture, and which was sent from the same dispatcher. Thus, sibutramine may have been present in that item.

Sibutramine products are not approved for use in Japan, but they are among the most popular anti-obesity agents sold on the Internet. Sibutramine is a serotonin reuptake inhibitor and noradrenaline reuptake inhibitor, and it induces weight loss through a combination of reduced appetite, feelings of satiety and, possibly, the induction of thermogenesis [23, 24]. However, some adverse cardiovascular events in patients treated with sibutramine have been reported [25]. Following data obtained from the Sibutramine Cardiovascular Outcomes Trial, sibutramine was withdrawn from the market in the USA, Canada, European Union and UK in 2010. The Committee for Medicinal Products for Human Use in the European Medicines Agency recommended that all marketing authorization for medicines containing sibutramine be suspended across the European Union [2630]. Weight-loss medicines such as herbal supplements disguised as diet-aid products can be acquired readily on the Internet. Some of those products may include harmful substances (e.g., sibutramine), so medicines and supplements purchased on the Internet can damage health.

Medicines may be categorized into two basic types: synthetic medicines and herbal medicines compounded from crude drugs. Often, herbal medicines and supplements are purported to have a lower prevalence of adverse effects than synthetic medicines. However, health 
Table 2 Sibutramine quantities

\begin{tabular}{lllll}
\hline Product number & Type of dosage form & Quantity $(\mathrm{mg} /$ unit) & Authenticity & Reason \\
\hline 1 & Soft capsule & $11.48 \pm 0.61$ & Falsified (suspected) & Mislabeled \\
2 & Soft capsule & $13.43 \pm 0.81$ & Falsified (suspected) & Mislabeled \\
3 & Soft capsule & $10.18 \pm 1.63$ & Falsified (suspected) & Mislabeled \\
4 & Soft capsule & $10.85 \pm 0.25$ & Falsified (suspected) & Mislabeled \\
5 & Soft capsule & $13.13 \pm 0.41$ & Falsified (suspected) & Mislabeled \\
6 & Soft capsule & $6.26 \pm 2.14$ & Falsified (suspected) & Mislabeled \\
7 & Soft capsule & $10.19 \pm 8.52$ & Falsified (suspected) & Mislabeled \\
8 & Hard capsule & $25.85 \pm 1.43$ & Falsified (suspected) & Mislabeled \\
9 & Hard capsule & $15.53 \pm 1.91$ & Falsified (suspected) & Mislabeled \\
10 & Hard capsule & $10.03 \pm 0.97$ & Falsified (suspected) & Mislabeled \\
11 & Hard capsule & $9.67 \pm 0.41$ & Falsified (suspected) & Mislabeled \\
12 & Hard capsule & $12.82 \pm 1.02$ & Falsified (suspected) & Mislabeled \\
13 & Hard capsule & $11.38 \pm 0.17$ & Falsified (suspected) & Mislabeled \\
14 & Sugarcoated tablet & Not detected & Genuine & The manufacturer did not or provide \\
& & & & results of chemical analyses \\
15 & Soft capsule & Not tested because of an & Unknown & \\
\hline
\end{tabular}

The quantity of sibutramine is represented as the mean \pm SD $(n=3)$

problems caused by Chinese herbal medicines containing aristolochic acid have been reported [20, 21, 31, 32]. Since 2002, in Japan, over 700 people (mostly women) have developed health problems after taking unapproved Chinese diet-aid products containing N-nitroso-fenfluramine [22]. In the present study, we found that herbal supplements purchased on the Internet contained sibutramine (a synthetic anti-obesity drug) but not aristolochic acid, fenfluramine, or N-nitroso-fenfluramine. These herbal supplements may be regarded as falsified products because they contained sibutramine, which was not listed as a component.

Our findings indicate clearly that herbal products purchased on the Internet carry the risk of adverse effects. It is necessary to halt the increase in the number of individuals becoming ill after taking medicines purchased on the Internet. Warnings need to be given about the careless use of products disguised as "weight-loss medicines" sold over the Internet. Consumers need to become more fully aware of the risks involved if they purchase such products from the Internet.

\section{Conclusions}

Products confirmed to be supplements and which underwent chemical analyses contained sibutramine, which can exert adverse cardiovascular events. Herbal products that contain harmful substances are distributed worldwide and any individual can obtain them through the Internet, even though the dangers of purchasing medicines and/or supplements online have been documented $[33,34]$. These products pose serious safety risks
[20-22, 35]. These fraudulent products should not be sold on the Internet but, for the moment, consumers should protect themselves by avoiding inappropriate use of pharmaceutical agents. To expedite access to genuine products for consumer safety, improved regulation of illegitimate medicines and supplements, increased inspection and guidance to comply with existing rules, and international cooperation by public-health agencies, drug regulatory bodies and law enforcement agencies could help ensure secure pharmaceutical distribution. Governments and individual consumers need to be more vigilant regarding the possible health risks associated with use of these bogus herbal preparations.

\section{Abbreviations}

(HPLC): High-performance liquid chromatography; (PDA): Photodiode array detector; (TLC): Thin-layer chromatography; (UV): Ultra violet; (WHO): World Health Organization.

\section{Competing interests}

The authors declare that they have no competing interests.

\section{Authors' contributions}

$\mathrm{NY}, \mathrm{MN}, \mathrm{YN}, \mathrm{T}$, and KK conceived and designed the experiments. NY, MN, $\mathrm{YN}, \mathrm{KU}, \Pi \mathrm{T}$ and $\mathrm{KK}$ carried out the experiments. NY, MN, YN, KU and $\Pi \mathrm{T}$ analyzed the data. $\Pi \mathrm{T}$ and $\mathrm{KK}$ contributed reagents/materials/analytical tools. NY wrote the first draft of the manuscript. MN, YN, KU, HT, TT, and KK contributed to writing of the manuscript. All authors read and approved the final version of the manuscript.

\section{Acknowledgement}

This work was supported by a Health and Labor Sciences Research Grant (Research on Regulatory Science of Pharmaceuticals and Medical Devices) from the Ministry of Health, Labor, and Welfare, Japan. 


\section{Author details}

'Drug Management and Policy, Faculty of Pharmacy, Institute of Medical, Pharmaceutical and Health Sciences, Kanazawa University, Kakuma-machi, Kanazawa, Ishikawa 920-1192, Japan. ${ }^{2}$ Faculty of Pharmaceutical Sciences, Doshisha Women's University, Kodo, Kyotanabe, Kyoto 610-0395, Japan.

Received: 22 June 2015 Accepted: 2 December 2015 Published online: 04 December 2015

\section{References}

1. World Health Organization: Medicines: spurious/falsely-labelled/ falsified/ counterfeit (SFFC) medicines. Fact sheet N²75, May 2012 [http://www.who. int/mediacentre/factsheets/fs275/en/] Accessed on June 18, 2013.

2. WHO: WHO's role in the prevention and control of medical products of compromised quality, safety and efficacy such as substandard/spurious/ falselylabelled/falsified/counterfeit medical products. February 2011. [http:// apps.who.int/gb/ssffc/pdf_files/A_SSFFC_WG3Rev1-en.pdf].

3. Attaran A, Barry D, Basheer S, Bate R, Benton D, Chauvin J, et al. How to achieve international action on falsified and substandard medicines. BM 2012;345:e7381. [http://www.bmj.com/content/345/bmj.e7381.full.pdf+html].

4. Ministry of Health, Labour and Welfare: Information for those who are bringing medicines for personal use into Japan. [http://www.mhlw.go.jp/ english/policy/health-medical/pharmaceuticals/01.html]

5. The Ministry of Health, Labour and Welfare in Japan: in Japanese. [http:// www.mhlw.go.jp/topics/bukyoku/iyaku/kojinyunyu/050609-1.html] Accessed on September 10, 2015.

6. The U.S. Food and Drug Administration: What can I do to help ensure I do not receive or take counterfeit medicine? September 19, 2013. [http://www. fda.gov/drugs/resourcesforyou/consumers/buyingusingmedicinesafely/ counterfeitmedicine/ucm235434.htm] Accessed on September 10, 2015.

7. The U.S. Food and Drug Administration: Helping Patients Avoid Counterfeit Drugs over the Internet. FDA Patient Safety News. Show \#67, September 2007. [http://www.fda.gov/downloads/Safety/FDAPatientSafetyNews/ UCM417854.pdf] Accessed on September 10, 2015.

8. European Medicines Agency: Falsified medicines. [http://www.ema.europa. eu/ema/index.jsp?curl=pages/special_topics/general/general_content_ 000186.jsp\&mid=WC0b01ac058002d4e8] Accessed on September 10, 2015.

9. Medicines and Healthcare Products Regulatory Agency in the United Kingdom. Counterfeit medicines: what pharmacists should know. December 11, 2014. [https://www.gov.uk/drug-safety-update/counterfeit-medicineswhat-pharmacists-should-know] Accessed on September 10, 2015.

10. Medicines and Healthcare Products Regulatory Agency in the United Kingdom. Yellow Card extended to include devices, counterfeits and defective medicines. January 22, 2015. [https://www.gov.uk/drug-safetyupdate/yellow-card-extended-to-include-devices-counterfeits-and-defectivemedicines] Accessed on September 10, 2015.

11. Health Canada: Policy on Counterfeit Health Products (POL-0048). [http:// www.hc-sc.gc.ca/dhp-mps/compli-conform/activit/pol_0048_counterfeitcontrefacon-eng.php] Accessed on September 10, 2015.

12. Therapeutic Goods Administration in Australia: Counterfeit medicines and medical devices. November 6, 2015. [http://www.tga.gov.au/counterfeitmedicines-and-medical-devices] Accessed on December 4, 2015.

13. Kimura K, Okumura J, Honma T, Osawa T, Araki R, Tanimoto T: Public health implication of personal import of medicines through internet brokers. Iryo To Shakai 18, 459-472, 2008. In Japanese. [https://www.jstage.jst.go.jp/ article/iken/18/4/18_4_459/_pdf]

14. Kimura K, Honma T, Tanimoto T, Takao C, Okumura J, Yoshida N, et al. Public health implication of personal import of medicines through internet brokers (2): buying Anti-obesity Agents on-line. Iryo To Shakai. 2011;21:5566. In Japanese. [https://www.jstage.jst.go.jp/article/iken/21/1/21_1_55/_ article/-char/ja/].

15. Araki R, Okumura J, Akazawa M, Kimura K. Survey of consumers' attitude toward personal import of medicines. Japanese J Soc Pharm. 2010;28:134-5 (in Japanese).

16. Khan MH, Tanimoto T, Nakanishi Y, Yoshida N, Tsuboi H, Kimura K: Public health concerns for anti-obesity medicines imported for personal use through the internet: a cross-sectional study. BMJ Open 2, 2012. [http:// bmjopen.bmj.com/content/2/3/e000854.full.pdf+html]

17. Ministry of Health, Labour and Welfare: the list of plant-origin materials used mainly as pharmaceutical medicine. In Japanese. [http://www.mhlw.go.jp/ file/06-Seisakujouhou-11130500-Shokuhinanzenbu/0000086062.pdf]
18. World Health Organization. Growing threat from counterfeit medicines. Bull World Health Organ. 2010;88:247-8.

19. Ministry of Health, Labour and Welfare: The Japanese Pharmacopoeia $16^{\text {th }}$ edition. 2011. [http://jpdb.nihs.go.jp/jp16e/].

20. Tanaka A, Nishida R, Maeda K, Sugawara A, Kuwahara T. Chinese herb nephropathy in Japan presents adult-onset Fanconi syndrome: could different components of aristolochic acids cause a different type of Chinese herb nephropathy? Clin Nephrol. 2000;53(4):301-6.

21. Tanaka A, Nishida R, Yoshida T, Koshikawa M, Goto M, Kuwahara T: Outbreak of Chinese herb nephropathy in Japan: are there any differences from Belgium? Intern Med. 40: 296-300, 2001. [https://www.jstage.jst.go.jp/article/ internalmedicine1992/40/4/40_4_296/_article].

22. Ministry of Health, Labour and Welfare: Health hazards by Chinese Weightloss Dietary Supplement (unapproved medicines). July 12, 2006. In Japanese. [http://www.mhlw.go.jp/houdou/2002/07/h0719-3.html] Accessed on June 20, 2013.

23. Luscombe GP, Hopcroft RH, Thomas PC, Buckett WR. The contribution of metabolites to the rapid and potent down-regulation of rat cortical betaadrenoceptors by the putative antidepressant sibutramine hydrochloride. Neuropharmacology. 1989;28(2):129-34. [http://ac.els-cdn.com/ 0028390889900488/1-s2.0-0028390889900488-main.pdf?_tid=64303698065b-11e4-a0fe-00000aab0f6b\&acdnat $=1404795212$ 2d759e9f17251c553134acb7f746a0a1]

24. Luque CA, Rey JA. The discovery and status of sibutramine as an antiobesity drug. Eur J Pharmacol. 2002;440(2-3):119-28. [http://ac.els-cdn.com/ S0014299902014231/1-s2.0-S0014299902014231-main.pdf?_tid=4b45166c065b-11e4-a752-00000aacb362\&acdnat=1404795170_ a6f3b37b1fc70bd5b0db00408daf1153].

25. Scheen AJ. Sibutramine on cardiovascular outcome. Diabetes Care. 2011;34 Suppl 2:S114-9. [http://care.diabetesjournals.org/content/34/Supplement_2/ S114.long].

26. James WPT. The SCOUT study: risk-benefit profile of sibutramine in overweight high-risk cardiovascular patients. Eur Heart J. 2005;7(Suppl L): L44-8. [http://eurheartjsupp.oxfordjournals.org/content/7/suppl_L/L44.full. pdf + html].

27. James WP, Caterson ID, Coutinho W, Finer N, Van Gaal LF, Maggioni AP, et al. SCOUT Investigators. Effect of sibutramine on cardiovascular outcomes in overweight and obese subjects. N Engl J Med. 2010;363(10):905-17. [http:// www.nejm.org/doi/pdf/10.1056/NEJMoa1003114].

28. U.S. Food and Drug Administration: Meridia (sibutramine): Market Withdrawal Due to Risk of Serious Cardiovascular Events. August 2010. [http://www.fda.gov/safety/medwatch/safetyinformation/safetyalertsfor humanmedicalproducts/ucm228830.htm] Accessed on May 21, 2014.

29. Mackey TK, Aung P, Liang BA: Illicit Internet availability of drugs subject to recall and patient safety consequences. Int J Clin Pharm. 2015 Jul 7. In press. [http://link.springer.com/article/10.1007\%2Fs11096-015-0154-8].

30. European Medicines Agency: Sibutramine. August 2010. [http://www.ema. europa.eu/ema/index.jsp?curl=pages/medicines/human/referrals/ Sibutramine/human_referral_000219.jsp].

31. Vanherweghem JL, Depierreux M, Tielemans C, Abramowicz D, Dratwa M, Jadoul M, Richard C, Vandervelde D, Verbeelen D, Vanhaelen-Fastre R, Vanhaelen M, Dratwa M, Richard C, Vandervelde D, Verbeelen D, Jadoul M: Rapidly progressive interstitial renal fibrosis in young women: association with slimming regimen including Chinese herbs. Lancet 13; 341 (8842): 387-91, 1993. [http://www.sciencedirect.com/science/article/pii/ 0140673693929842].

32. Nortier JL, Martinez MC, Schmeiser HH, Arlt VM, Bieler CA, Petein M, et al. Urothelial carcinoma associated with the use of a Chinese herb (Aristolochia fangchi). N Engl J Med. 2000;342(23):1686-92. [http://www.nejm.org/doi/ pdf/10.1056/NEJM200006083422301].

33. Jackson G, Patel S, Khan S. Assessing the problem of counterfeit medications in the United Kingdom. Int J Clin Pract. 2012;66(3):241-50.

34. Blackstone EA, Fuhr Jr JP, Pociask S. The health and economic effects of counterfeit drugs. Am Health Drug Benefits. 2014;7(4):216-24.

35. Debelle FD, Vanherweghem JL, Nortier JL. Aristolochic acid nephropathy: a worldwide problem. Kidney Int. 2008:74(2):158-69. 